\title{
Assessment of Dietary Exposure and Health Risk to Multiple Heavy Metals amongst Some Workers in Yaoundé, Cameroon
}

Angèle N. Tchana ${ }^{1}$, Nina D. Kamnang ${ }^{1}$, Arielle T. Maliedje ${ }^{1}$, Faustin T. Manfo ${ }^{2}$, Frederic N. Njayou ${ }^{1}$, Wilfred A. Abia $^{1}$, Edouard A. Nantia ${ }^{3}$ and Paul F. Moundipa ${ }^{1}$

1. Laboratory of Pharmacology and Toxicology, Department of Biochemistry, Faculty of Science, University of Yaoundé I, Yaoundé P.O. Box 812, Cameroon

2. Department of Biochemistry and Molecular Biology, Faculty of Science, University of Buea, Buea P.O.Box 63, Cameroon

3. Department of Biochemistry, Faculty of Science, University of Bamenda, Bambili P.O.Box 39, Cameroon

\begin{abstract}
This study reports on the dietary exposure of people in Yaoundé, Cameroon to heavy metals: lead (Pb), cadmium (Cd), mercury (Hg), copper $(\mathrm{Cu})$ and zinc $(\mathrm{Zn})$. One hundred and fifty table-ready food, water and soft drink samples were collected from households and street restaurants in Yaoundé and analyzed for heavy metals contents using atomic absorption spectrophotometer. Lead (93\%, range 0.019-1.77 ppm), Cd (70\%, range 0.01-4.68 ppm), Hg (81\%, range 0.03-10.56 ppm), Cu (90\%, range 0.004-40.32 ppm) and Zn (87\%, range 0.014-2,447.04 ppm) were detected in studied samples. Maximum level of each metal exceeded its corresponding European Commissions legislative limits. Samples from street restaurants were most tainted with heavy metals. The highest average daily intakes (ADIs) of $\mathrm{Pb}$ (0.96 mg/day) and $\mathrm{Hg}$ (1.84 mg/day) were through tap water, while Cd (1.15 mg/day), Cu (5.42 mg/day) and Zn (601.6 mg/day) were through rice/peanut sauce mixed food. The ADI for Cd and Hg was each higher than its respective PTDI (provisional tolerable daily intake) as defined by JECFA (Joint FAO/WHO Expert Committee on Food Additives) and EVM (Expert Group on Vitamins and Minerals). The estimated average daily exposure dose of each detected metal significantly ( $p=0.001$ ) exceeded its corresponding PTDI. However, the health risk index was $<1$ for all studied samples and it was found to be safe, indicating there is a relative absence of health risks associated with the ingestion of contaminated foods, water and soft drinks. Notwithstanding, the detected levels and ADI being higher than legislative limits and PTDI respectively speculates need for awareness raising towards reducing exposure levels to heavy metals in Cameroon.
\end{abstract}

Key words: Dietary exposure, food, water and soft drink contamination, heavy metals, Cameroon.

\section{Introduction}

Heavy metals are environmental pollutants prevalent in the surroundings as a result of natural and anthropogenic activities. Human exposure to heavy metals occurs through industrial activities, water supplies, automobile exhausts, disposal current, consumer products, application of fertilizers in soil, pesticides, urban effluents, and food [1, 2]. Some heavy metals $(\mathrm{Zn}$ and $\mathrm{Cu})$ are essential for normal cell

Corresponding author: Paul F. Moundipa, Ph.D., professor, research fields: biochemistry. physiology when present in low amounts, but exhibit toxicity to living organisms when taken up in high quantity, or if the mechanisms of elimination are impaired. Other heavy metals such as $\mathrm{Pb}, \mathrm{Cd}$, and $\mathrm{Hg}$ have no known benefit to human physiology, and are essentially referred to as toxicants or "toxic metals". Heavy metals enter the food chain where they tend to bioaccumulate particularly because of the ability of plants to uptake the chemicals [3-5].

The presence of heavy metals in the animal production chain can result from consumption of contaminated agricultural commodities and/or related products. Animal feed can also be intentionally 
supplemented with mineral raw materials during breeding [6, 7]. Heavy metals have also been reported in commercially available foods [8], given the likelihood of contamination of some commonly used raw materials (meat, plants).

They can enter the body by inhalation, dermal absorption, or ingestion [9]. Once into the organism they slowly accumulate in target organs such as the kidneys, lungs, liver, teeth, bones, brain and keratinized tissues such as hair and nails $[4,10,11]$. Heavy metals can form metal ion and induce reactive oxygen species (ROS) production, with subsequent lipid peroxidation, DNA damages and protein denaturation $[12,13]$. These toxicity mechanisms are common in some pathologies such as the reproductive system and development disorders, neurodegenerative diseases, metabolic diseases, kidney disorders and respiratory problems [4, 14-16]. Being ubiquitous and not easily biodegradable, heavy metals can persist in the environment and notably in the food chain with important human health risks. Indeed, many health implications such as cancer [17, 18], Alzheimer's disease, Parkinson's disease [15, 19] caused by consumption of food contaminated with $\mathrm{Hg}, \mathrm{Pb}, \mathrm{Cd}$, etc., have been reported.

Previous studies also highlighted sources, potential human health risks and high concentrations of heavy metals in commonly consumed foods and items in some developing countries like Bangladesh [20, 21], Ghana [2, 6, 22], Nigeria [6, 23], Uganda [24], Cameroon [25, 26]. Considering the susceptibility of to heavy metals exposure and insufficient data related to exposure levels, there is need to get information on the heavy metals dietary exposure levels amongst Cameroonians. The aim of this study was to determine the extent to which the population of Yaoundé in Cameroon is exposed to heavy metals in their diets, water and/or soft drinks commonly prepared at homes and/or bought from small road-side restaurants for direct consumption.

\section{Materials and Methods}

\subsection{Reagents and Equipment}

The reagents used in the experiment were high grade and purchased from Sigma Aldrich (USA), Prolabo (France), Merck (Germany). Demineralized water was used wherever needed. Working standard solutions (100 ppm in 1\% nitric acid) of $\mathrm{Pb}, \mathrm{Cd}, \mathrm{Hg}$, $\mathrm{Cu}$ and $\mathrm{Zn}$ were prepared from the stock solutions having 1,000 ppm followed by appropriate dilution. Atomic absorption spectrophotometer (Buck Scientific, In., Fort Point St., USA) was used for metals determination. Glassware and tubes were pre-washed with $10 \%$ nitric acid solution to avoid additional metal contamination of samples.

\subsection{Study Site and Study Population}

A descriptive cross-sectional survey was conducted in 2013 among the population (age between 21 and 65 years) in all the 23 districts of Yaoundé, Center region of Cameroon. Yaoundé is the administrative capital of Cameroon, and the second cosmopolitan city in the country after Douala (the economic capital). Yaoundé is characterized by wide diversified individually owned small road-side restaurants that attempting to provide foods and related services to the busy population of Yaoundé, working in diversity of jobs life and in Yaoundé sorely to fend for themselves and families. Thus, the study population was essentially people leaving and working in the city of Yaoundé, regardless of their occupations, e.g., students, employees, informal sectors workers (traders, mechanics, sheet metal workers, welders, taxi drivers ...), and/or unemployed.

\subsection{Survey on Foods/Snacks, Water and Soft Drinks Consumptions}

Semi-structured (and food frequency) questionnaires were used to collect information on lifestyle, nutritional habits, the origin of various foodstuffs, 
food preparation method, food consumption intake/amounts and frequency (per day/week/month), amount ingested, storage behavior, medical background from each participants (those who had signed the informed consent form).

\subsection{Sampling}

One hundred and fifty (150) samples consisted of mixed food dishes, food items and beverages (Table 1) were randomly collected or purchased from households and/or small road-side restaurants in Yaoundé from February to March 2013. Solid and liquid samples that were not pre-packaged e.g., tap water, foods in plates ready for consumption, were mixed thoroughly prior to sample collection. Pre-packaged samples e.g., soft drinks in cocked bottles, sardine in cans, sachet/bottled water, were collected in their natural packaging as found in the study households and/or small road-side restaurants (i.e., in plastic bags, cans). Both non- and pre-packaged samples collected were immediately placed into an ice cooler, and transferred to the Laboratory of Pharmacology and Toxicology of the University of Yaoundé I, where samples were pre-processed before analysis. Each solid sample was weighed, meanwhile, mixed food dishes such as paste with sauce commonly eaten in combination were mixed to make a single sample of the final consumed food. Each of the weighed solid samples was then milled, and after thorough mixing, a sub-sample (100 g) was placed in sterile glass container, sealed and preserved at $-20{ }^{\circ} \mathrm{C}$ until analysis of heavy metals. Similarly, each liquid sample (beverages) was mixed thoroughly and a sub-sample $(100 \mathrm{~mL})$ was placed in sterile glass bottle, sealed and preserved at $-20{ }^{\circ} \mathrm{C}$ until analysis of heavy metals.

Table 1 Sample types collected from all 23 districts in Yaoundé, Centre Region of Cameroon.

\begin{tabular}{|c|c|c|c|}
\hline Sample type & $\begin{array}{l}\text { Number of } \\
\text { samples }\end{array}$ & Food-base & $\begin{array}{l}\text { Cooking method } \\
\text { /Storage material }\end{array}$ \\
\hline $\begin{array}{l}\text { Corn paste + (Okra soup, cabbage sauce, } \\
\text { "djama-djama", "ndolèa” sauce) }\end{array}$ & 12 & Cereals (corn) & Boiling/Plastic \\
\hline Cassava paste + (egusi sauce ${ }^{\mathrm{a}}$, "eru”") & 8 & Tuber (cassava flour) & Boiling/Plastic \\
\hline Cocoyam paste + peanut sauce ${ }^{a}$ & 7 & Tuber ( cocoyam), leguminous (peanut) & Boiling/Plastic \\
\hline Rice + (stew soup, peanut sauce) & 22 & Cereals (rice) & Boiling/Plastic \\
\hline Doughnut & 12 & Cereals (wheat, corn) & Frying/Plastic \\
\hline Porridge & 6 & $\begin{array}{l}\text { Cereals (corn, rice), leguminous } \\
\text { (peanut, beans) }\end{array}$ & Boiling/Plastic \\
\hline Beans & 3 & $\begin{array}{l}\text { Leguminous (beans), tuber (sweet } \\
\text { potato) }\end{array}$ & Boiling, frying/Plastic \\
\hline Fish + cassava paste & 5 & Fish, tuber (cassava) & Roasting/Plastic \\
\hline Sausage/pie meat & 4 & - & Preserved/Can \\
\hline Sardine & 4 & - & Preserved/Can \\
\hline Tomato & 7 & - & Preserved//Plastic, Can \\
\hline Milk $^{\dagger}$ & 6 & - & Bottled/Plastic \\
\hline Refined oil/Palm oil & 6 & - & Bottled/Plastic \\
\hline Soft drink ${ }^{\dagger}$ & 11 & & Bottled/Plastic \\
\hline Mineral water ${ }^{\dagger}$ & 4 & - & Bottled/Plastic \\
\hline Sachet water ${ }^{\dagger}$ & 15 & & Package/Plastic \\
\hline Spring water ${ }^{\dagger}$ & 3 & & Package/Plastic \\
\hline Water-well $^{\text {at }}$ & 8 & & -/Plastic \\
\hline Tap water $^{\mathrm{a} \dagger}$ & 7 & & -/Plastic \\
\hline Total & 150 & & \\
\hline
\end{tabular}

${ }^{\mathrm{a}}$ : Samples originating from households; ${ }^{\dagger}$ : liquid samples. 


\subsection{Heavy Metals Analysis}

Wet digestion was conducted on $2 \mathrm{~g}$ of food or soft drink samples introduced in a flask, except water samples, with $20 \mathrm{~mL}$ of aqua regia (nitric acid $(75 \%) /$ hydrochloric acid (36\%): 1:3 v/v). The flask was placed in a reflux device and heated at $80{ }^{\circ} \mathrm{C}$ for 2 to 3 hours until the solution become clear [27]. The digest was allowed to cool and transferred into a measuring flask using specific Whatman filter paper for metals. The filtrate was then made up to $50 \mathrm{~mL}$ using demineralized water and stored at the same time with $50 \mathrm{~mL}$ each water sample at $4{ }^{\circ} \mathrm{C}$. Samples were mineralized in duplicate for $\mathrm{Cd}, \mathrm{Pb}, \mathrm{Hg}, \mathrm{Cu}$ and $\mathrm{Zn}$ determination by atomic absorption spectrophotometry [28]. Briefly, $25 \mathrm{~mL}$ of mineral deposit of the test sample was introduced into the air-acetylene flame (lamp current of $4 \mathrm{~mA}$ ) of the spectrophotometer in which it was vaporized and atomized. Wavelengths of $288.8 \mathrm{~nm}, 217 \mathrm{~nm}, 253.7$ $\mathrm{nm}, 324.8 \mathrm{~nm}$, and $213.9 \mathrm{~nm}$ were used respectively for $\mathrm{Cd}, \mathrm{Pb}, \mathrm{Hg}, \mathrm{Cu}$ and $\mathrm{Zn}$. Concentration (ppm) of metal was read after calibration of the instrument with known concentrations of the metals solutions: 2.5, 5.0, 10, 15, 20 ppm and reagent blank for $\mathrm{Pb} ; 5.0,10,15$, $20 \mathrm{ppm}$ and reagent blank for $\mathrm{Cd}$ and $\mathrm{Hg}$; and 1, 2.0, 3.0, 4.0, $5.0 \mathrm{ppm}$ and reagent blank for $\mathrm{Cu}$ and $\mathrm{Zn}$.

\subsection{Exposure Assessment Calculations}

2.6.1 Calculating the Average Daily Intake (ADI) of Heavy Metals

The studied samples were broadly categorized into food, water and soft drink. The ADI of a metal in a food was determined by multiplying the average content of the metal in food by the averaged consumed amount of food and frequency of consumption [29], using the following formula:

$\mathrm{ADI}=\Sigma(\mathrm{T}$ food or beverages $\times \mathrm{Q}$ ingested $\times \mathrm{F}$ food) $/ 30$

where, ADI = average daily intake of metal (mg/day); $\mathrm{T}=$ heavy metal content in the food ingested $(\mathrm{mg} / \mathrm{kg}$ or $\mathrm{mg} / \mathrm{L}$ ); $\mathrm{Q}$ ingested $=$ weight of the food consumed (g) and $\mathrm{F}=$ frequency of consumption of a food over 30 days.

2.6.2 Estimation of Daily Exposure to Heavy Metals in the Study Population

Average daily exposure dose (ADED). The daily exposure dose of heavy metals (DED) was calculated using the following formula [29] and the survey data:

$\mathrm{ADED}=\mathrm{ADI} / \mathrm{bw}$

where $\mathrm{ADED}=$ the average daily exposure dose to heavy metal $(\mu \mathrm{g} / \mathrm{kg}$ bw/day) and bw = body weight of individual $(\mathrm{kg})$. The average body weight of $60.7 \mathrm{~kg}$ for African (adult) as established by WHO [30] was used in this study.

Contribution rate of metal exposure. The contribution rate of metal exposure from collected samples was determined as followed:

Food contribution rate of metal exposure $=($ metal exposure of the sample/total dietary metal exposure) $\times 100 \%$

Health risk index (HRI). The potential HRI to consumers which refers to the ratio of the daily exposure dose of metals to the oral reference dose was determined according to EPA [31] as followed:

$$
\mathrm{HRI}=(\mathrm{ADED} / \mathrm{PTDI}) \times 10^{-3}
$$

where PTDI is the provisional tolerable daily intake reference dose of the metal and $10^{-3}$ factor of uncertainty (conversion factor). HRI $>1$ indicates a reason for health concern.

\subsection{Statistical Analyses}

The software statistical package for social sciences (SPSS 20.0) was used for data analysis. Data were presented as mean \pm standard deviation. Mann-Whitney $U$, Kruskal-Wallis for non-normally distributed data, analysis of variance (ANOVA) and Student $t$-tests for parametric data were used to compare groups. Correlation analysis was done using Chi-square test. A $p$-value $<0.05$ was considered statistically significant. 


\subsection{Ethical Statement}

The experimental procedure was approved by the Cameroon National Ethics Committee of Research for Human Health (No. 2013/05/252/CNERSH/SP).

\section{Results}

\subsection{Characteristics of the Population}

The studied population (251 individuals) was mostly informal sector workers $(70 \%)$ followed by students (16\%), employees (12\%) and others (3\%). About $67 \%$ of participants used to eat both in small road-side or street restaurants and households, while $22 \%$ and $11 \%$ eat in households, small road-side restaurants, respectively (Fig. 1). There was a significant correlation between the catering and status of participants $(p=0.001)$, with people involved in small businesses feeding mainly in the small road-side or street restaurant (Fig. 1).

\subsection{Levels of Heavy Metals in Food and Foodstuff Samples}

The contamination profile of samples as well as the mean concentrations of heavy metal in broader groups regarded to guidelines is summarized in Table 2. Lead was detected in $93 \%$ of samples (range 0.019-1.77 ppm), $\mathrm{Cd}$ in $70 \%$ (range $0.01-4.68 \mathrm{ppm}$ ), $\mathrm{Hg}$ in $81 \%$ (range $0.03-10.56 \mathrm{ppm}$ ), $\mathrm{Cu}$ in $90 \%$ (range
$0.004-40.32 \mathrm{ppm}$ ) and $\mathrm{Zn}$ in $87 \%$ of samples (range 0.014-2,447.04 ppm). Highest levels of metals were recorded in samples from the small road-side restaurants and were 8 to 105.6 folds more than permitted [32, 33]. Differences in $\mathrm{Pb}, \mathrm{Cu}$ and $\mathrm{Zn}$ values were significant $(p=0.001)$ between the studied household and small road-side restaurant foods.

The average concentrations of metals in water samples varied from 0.019 to $0.9 \mathrm{ppm}$ for $\mathrm{Pb}, 0.01$ to $0.58 \mathrm{ppm}$ for $\mathrm{Cd}, 0.03$ to $1.13 \mathrm{ppm}$ for $\mathrm{Hg}, 0.004$ to $2.02 \mathrm{ppm}$ for $\mathrm{Cu}$ and 0.014 to $0.41 \mathrm{ppm}$ for $\mathrm{Zn}$ with no significant difference $(p>0.05)$. The concentrations of $\mathrm{Pb}, \mathrm{Cd}$ and $\mathrm{Hg}$ in $100 \%$ positive samples were higher than recommended $[32,33]$. and were in the following respective ranges in specify samples: sachet water (0.019-0.83 ppm, 0.02-0.58 ppm and 0.03-1.13 ppm); tap water (0.02-0.48 ppm, 0.07-0.27 ppm and 0.27-0.92 ppm); water from wells $(0.02-0.38 \mathrm{ppm}$, $0.02-0.38 \mathrm{ppm}$ and $0.24-0.89 \mathrm{ppm})$; spring water (0.06-0.42 ppm, 0.07-0.13 ppm and 0.1-0.51 ppm); and mineral water $(0.02-0.9 \mathrm{ppm}, 0.01-0.16 \mathrm{ppm}$ and 0.06-0.83 ppm).

The average concentrations of metals in soft drink samples were not significantly different $(p>0.05)$. The concentrations of metals in bottled soft drink and sachet soft drink ranged respectively as followed: $\mathrm{Pb}$ (0.54-1.28; 0.18-1.34 ppm), Cd (1.24-4.68; 0.6-2.35 ppm),

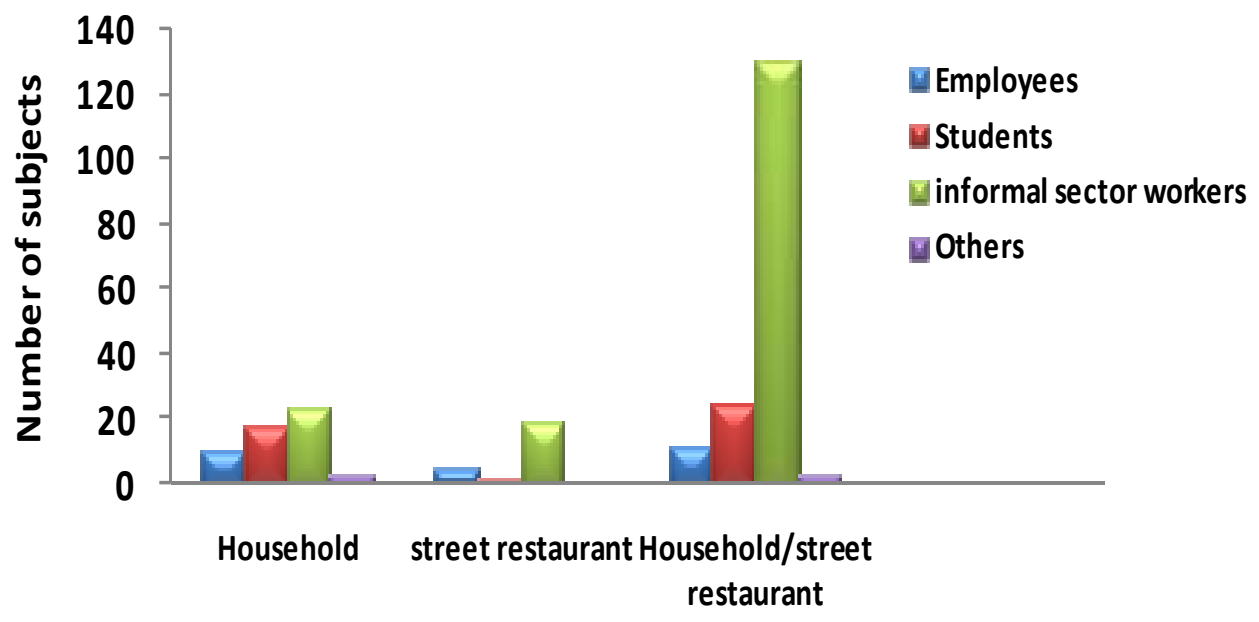

Fig. 1 Distribution of participants $(n=251)$ by feeding milieu. 

Metals amongst Some Workers in Yaoundé, Cameroon

Table 2 Occurrence and mean concentrations of heavy metals in samples groups.

\begin{tabular}{|c|c|c|c|c|c|c|}
\hline & Heavy metal & $\mathrm{Pb}$ & $\mathrm{Cd}$ & $\mathrm{Hg}$ & $\mathrm{Cu}$ & $\mathrm{Zn}$ \\
\hline \multirow{2}{*}{$\begin{array}{l}\text { Sample analyzed }(n \\
=150)\end{array}$} & Positive (\%) & $139(93)$ & $105(70)$ & $122(81)$ & $135(90)$ & $131(87)$ \\
\hline & Mean range (ppm) & $0.019-1.77$ & $0.01-4.68$ & $0.03-10.56$ & $0.004-40.32$ & $0.014-2,447.04$ \\
\hline \multicolumn{7}{|l|}{ Feeding milieu } \\
\hline \multirow{3}{*}{ Household $(n=22)$} & Positive (\%) & $20(91)$ & $18(82)$ & $18(82)$ & $19(86)$ & $18(82)$ \\
\hline & Mean range (ppm) & $0.02-1.22$ & $0.02-0.97$ & $0.04-0.92$ & $0.02-17.64$ & $0.02-557.2$ \\
\hline & Mean \pm SD & $0.21 \pm 0.21$ & 0.18 & $0.36 \pm 0.01$ & $1.95 \pm 0.26$ & $27.44 \pm 0.21$ \\
\hline \multirow{4}{*}{$\begin{array}{l}\text { Street or small } \\
\text { road-side restaurant } \\
(n=128)\end{array}$} & Positive (\%) & $115(90)$ & $87(68)$ & $104(81)$ & $116(91)$ & $113(88)$ \\
\hline & Mean range (ppm) & $0.019-1.77$ & $0.01-4.68$ & $0.03-10.56$ & $0.004-40.32$ & $0.014-2,447.04$ \\
\hline & Mean \pm SD & 0.5 & $0.76 \pm 0.18$ & $0.46 \pm 0.22$ & $9.51 \pm 3.06$ & $143.12 \pm 49.73$ \\
\hline & $p$-Value & 0.001 & 0.054 & 0.559 & 0.001 & 0.001 \\
\hline \multicolumn{7}{|l|}{ Sample group } \\
\hline \multirow{6}{*}{$\begin{array}{l}\text { Water } \\
(n=37)\end{array}$} & Positive (\%) & $37(100)$ & $34(91.9)$ & $31(83.8)$ & $30(81)$ & $34(91.9)$ \\
\hline & Mean range (ppm) & 0.019-0.9 & $0.01-0.58$ & $0.03-1.13$ & $0.004-2.02$ & $0.014-0.41$ \\
\hline & Mean \pm SD & $0.19 \pm 0.23$ & $0.14 \pm 0.12$ & $0.38 \pm 0.32$ & $0.13 \pm 0.34$ & $0.1 \pm 0.11$ \\
\hline & (\%) Above guideline & 100 & 100 & 100 & - & - \\
\hline & Guidelines (ppm) & $0.01 *$ & $0.003 *$ & $0.001 *$ & $2^{*}$ & $3 *$ \\
\hline & $p$-Value & 0.334 & 0.184 & 0.198 & 0.116 & 0.247 \\
\hline \multirow{6}{*}{ Soft drinks $(n=11)$} & Positive (\%) & $11(100)$ & $9(81.81)$ & $10(90.9)$ & $11(100)$ & $8(72.72)$ \\
\hline & Mean range (ppm) & $0.18-1.34$ & $0.6-4.68$ & $0.03-0.83$ & $2.29-40.32$ & $3.31-16.71$ \\
\hline & Mean \pm SD & $0.85 \pm 0.4$ & $1.71 \pm 1.42$ & $0.35 \pm 0.28$ & $18 \pm 12.41$ & $7.36 \pm 6.11$ \\
\hline & (\%) Above guideline & 100 & 100 & 100 & 90.9 & 63.63 \\
\hline & Guidelines (ppm) & $0.05 *$ & $0.4-0.5^{*}$ & $0.01 *$ & $5^{*}$ & $5^{*}$ \\
\hline & $p$-Value & 0.361 & 0.408 & 0.522 & 1 & 0.357 \\
\hline \multirow{6}{*}{$\begin{array}{l}\text { Food } \\
(n=102)\end{array}$} & Positive (\%) & $91(89.21)$ & $62(60.78)$ & $81(79.41)$ & $94(92.15)$ & $89(87.25)$ \\
\hline & Mean range (ppm) & $0.02-1.77$ & $0.13-3.5$ & $0.03-10.56$ & $0.03-38.56$ & $1.73-2,447.04$ \\
\hline & Mean \pm SD & $0.54 \pm 0.43$ & $0.76 \pm 0.95$ & $0.49 \pm 1.14$ & $10.36 \pm 8.02$ & $184 \pm 432$ \\
\hline & (\%) Above guideline & 100 & 100 & 72.54 & - & 16.66 \\
\hline & Guidelines (ppm) & $0.1^{*}$ & $0.05 *$ & $0.1^{*}$ & $100 *$ & $300 *$ \\
\hline & $p$-Value & 0.001 & 0.582 & 0.488 & 0.033 & 0.001 \\
\hline
\end{tabular}

SD: Standard deviation, *: Permissible limits [32, 33]. Analysis of variables was done by Kruskal-Wallis and Mann-Whitney $U$ tests. Significance at $p$-value $<0.05$

$\mathrm{Hg} \quad(0.04-0.83 ; 0.03-0.67 \mathrm{ppm}), \mathrm{Cu} \quad(5.37-40.32$; 2.29-35.5 ppm) and Zn (9.66-16.71; 3.31-10.61 ppm). The levels of $\mathrm{Pb}, \mathrm{Cd}$ and $\mathrm{Hg}$ in samples exceeded the allowances [32, 33].

In food group samples, the concentrations ranged from 0.02 to $1.77 \mathrm{ppm}$ for $\mathrm{Pb}, 0.13$ to $3.5 \mathrm{ppm}$ for $\mathrm{Cd}$, 0.03 to $10.56 \mathrm{ppm}$ for $\mathrm{Hg}, 0.03$ to $38.56 \mathrm{ppm}$ for $\mathrm{Cu}$ and 1.73 to $2,447.04$ for $\mathrm{Zn}$, and differed significantly ( $p<$ 0.05 ) for $\mathrm{Pb}, \mathrm{Cu}$ and $\mathrm{Zn}$. The maximum levels for $\mathrm{Pb}$, $\mathrm{Cd}, \mathrm{Hg}, \mathrm{Cu}$ and $\mathrm{Zn}$ were found respectively in refined oil, corn paste/vegetable sauce mixed food, cocoyam paste/peanut sauce mixed food, cassava paste/egusi sauce mixed food and cassava paste/vegetable mixed food (water "fufu/eru").

\subsection{Heavy Metal Contents according to Storage Behaviour}

The concentrations varied significantly $(p<0.05)$ depending on the natural packaging of samples collected as found in the field (Table 3), as far as $\mathrm{Pb}$, $\mathrm{Cu}$ and $\mathrm{Zn}$ were concerned. Levels of heavy metals were generally higher in samples stored in plastic bags relative to those in can, the two storage material mostly encountered in the feeding areas. 
Table 3 Levels of heavy metals (ppm) according to storage behavior.

\begin{tabular}{lllll}
\hline Heavy metal & Storage material & Number of positive samples & Mean \pm SD (range) & $p$-Value \\
\hline $\mathrm{Pb}$ & Plastic $(n=133)$ & 119 & $0.43(0.19-1.77)$ & $0.027^{*}$ \\
& Can $(n=17)$ & 16 & $0.74(0.02-1.7)$ & 0.845 \\
$\mathrm{Cd}$ & Plastic $(n=133)$ & 95 & $0.69 \pm 0.75(0.1-4.67)$ & \\
& Can $(n=17)$ & 10 & $0.57 \pm 0.75(0.19-1.82)$ & 0.325 \\
$\mathrm{Hg}$ & Plastic $(n=133)$ & 110 & $0.47 \pm 0.42(0.03-10.56)$ & $0.001^{*}$ \\
& Can $(n=17)$ & 12 & $0.30 \pm 0.41(0.03-1.7)$ & \\
$\mathrm{Cu}$ & Plastic $(n=133)$ & 118 & $7.64 \pm 7.12(0.004-40.32)$ & $0.001^{*}$ \\
$\mathrm{Zn}$ & Can $(n=17)$ & 17 & $14.32 \pm 7.12(2.93-30.73)$ & \\
& Plastic $(n=133)$ & 114 & $119.31 \pm 178.96(0.14-2,447.04)$ & \\
& Can $(n=17)$ & 17 & $179.72 \pm 178.9(16-670)$ & \\
\hline
\end{tabular}

Mean \pm SD: Mean \pm Standard deviation, *: significantly different for $p<0.05$.

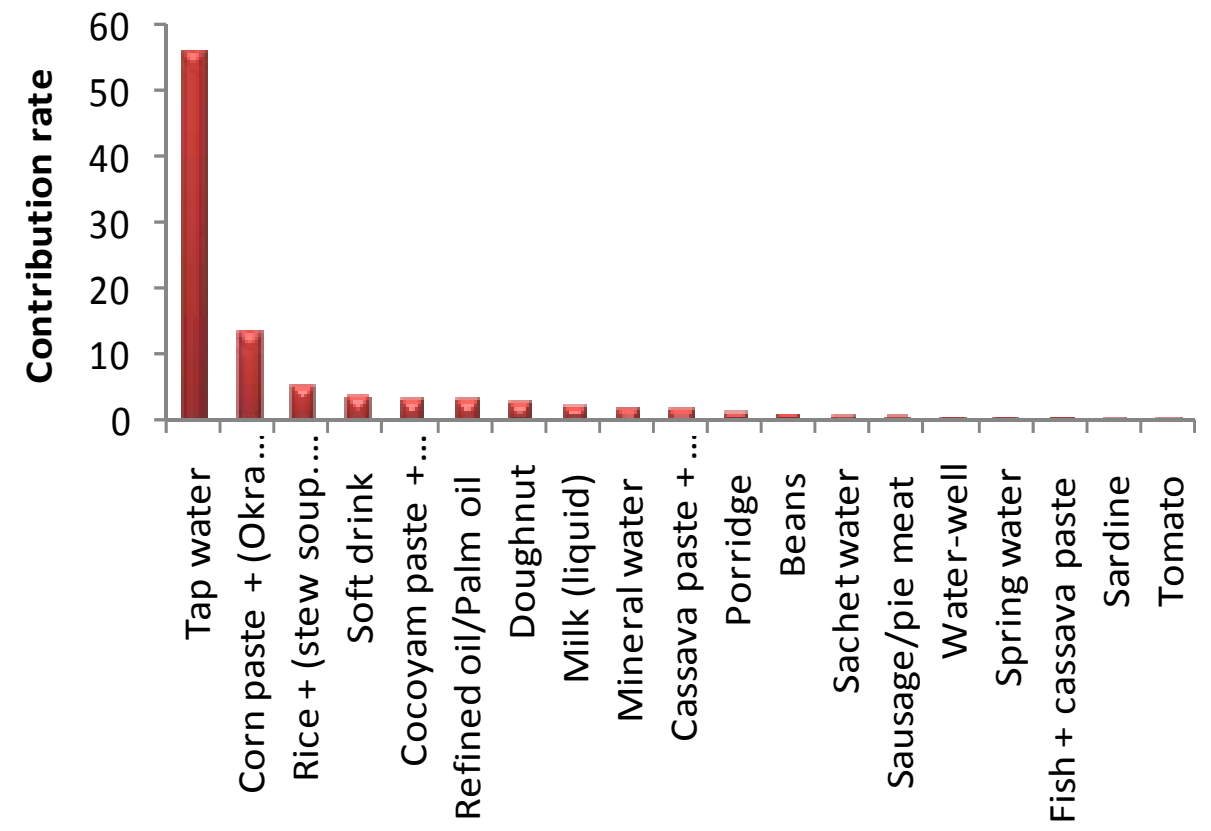

Fig. 2 Contribution of sample types lead exposure.

\subsection{Estimated ADI of Heavy Metals in Sample Groups}

Daily intake of heavy metals was estimated and presented in Table 4 below. A significant difference ( $p$ $<0.05)$ was observed between the ADI of $\mathrm{Hg}(0.19$ $\mathrm{mg} / \mathrm{d})$ through water consumption and $\mathrm{Pb}(0.09 \mathrm{mg} / \mathrm{d})$, $\mathrm{Cd}(0.07 \mathrm{mg} / \mathrm{d}), \mathrm{Cu}(0.07 \mathrm{mg} / \mathrm{d}), \mathrm{Zn}(0.07 \mathrm{mg} / \mathrm{d})$. There was no such significant difference with regard to soft drink and food group samples. Dietary intake of $\mathrm{Cd}, \mathrm{Cu}$ and $\mathrm{Zn}$ through soft drink consumption $(0.14 ; 1.34$ and $0.59 \mathrm{mg} / \mathrm{d}$ respectively) and food consumption $(0.1 ; 1.11$ and $29.45 \mathrm{mg} / \mathrm{d}$ respectively) were significantly different $(p<0.05)$ when compared to those of $\mathrm{Pb}(0.07$ and $0.06 \mathrm{mg} / \mathrm{d})$ and $\mathrm{Hg}(0.03$ and $0.07 \mathrm{mg} / \mathrm{d}$ ).

\subsection{Exposure Level of Participants to Heavy Metals}

Considering an average body weight of $60.7 \mathrm{~kg}$ adult Cameroonian, and on the basis of the food survey questionnaire data, the estimated daily heavy metal exposures in the studied population are presented in Figs. 2-6. The average exposure dose of $\mathrm{Pb}, \mathrm{Cd}, \mathrm{Hg}, \mathrm{Cu}$ and $\mathrm{Zn}$ in the population was estimated to be $18.37 \mu \mathrm{g} / \mathrm{kg} . \mathrm{bw} / \mathrm{d} ; 23.10 \mu \mathrm{g} / \mathrm{kg} . \mathrm{bw} / \mathrm{d}$; $21.74 \mu \mathrm{g} / \mathrm{kg} . \mathrm{bw} / \mathrm{d} ; \quad 210 \mu \mathrm{g} / \mathrm{kg} . \mathrm{bw} / \mathrm{d}$ and 2,830 $\mu \mathrm{g} / \mathrm{kg} . \mathrm{bw} / \mathrm{d}$ and were significantly different $(p=0.001)$, 
meanwhile, their health risk indexes (HRIs) were all below one (Table 4) and relative contribution rates of sample are presented in Table 5. The exposure doses in the categorized groups of participants presented in
Table 6 showed a positive association $(p<0.05)$ between professional status and exposure levels of $\mathrm{Pb}$ and Hg. Individuals working in small business and others were the most exposed.

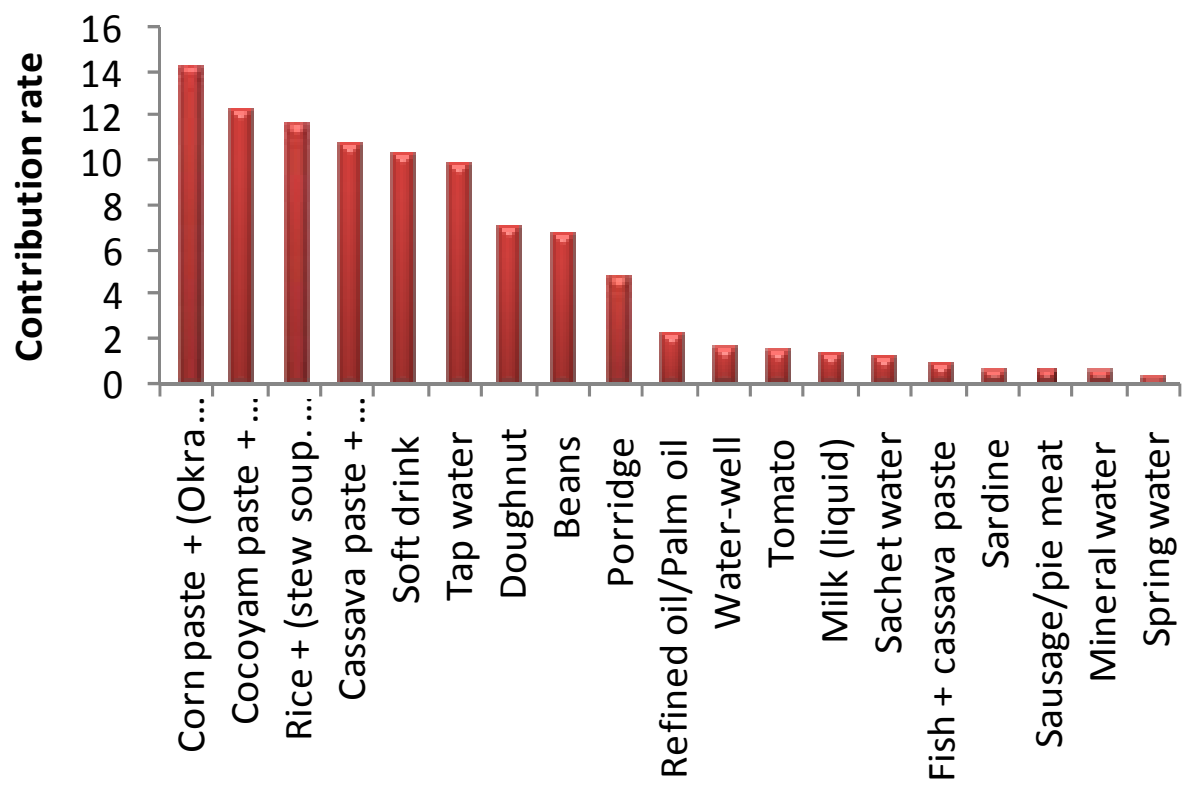

Fig. 3 Contribution of sample types to cadmium exposure.

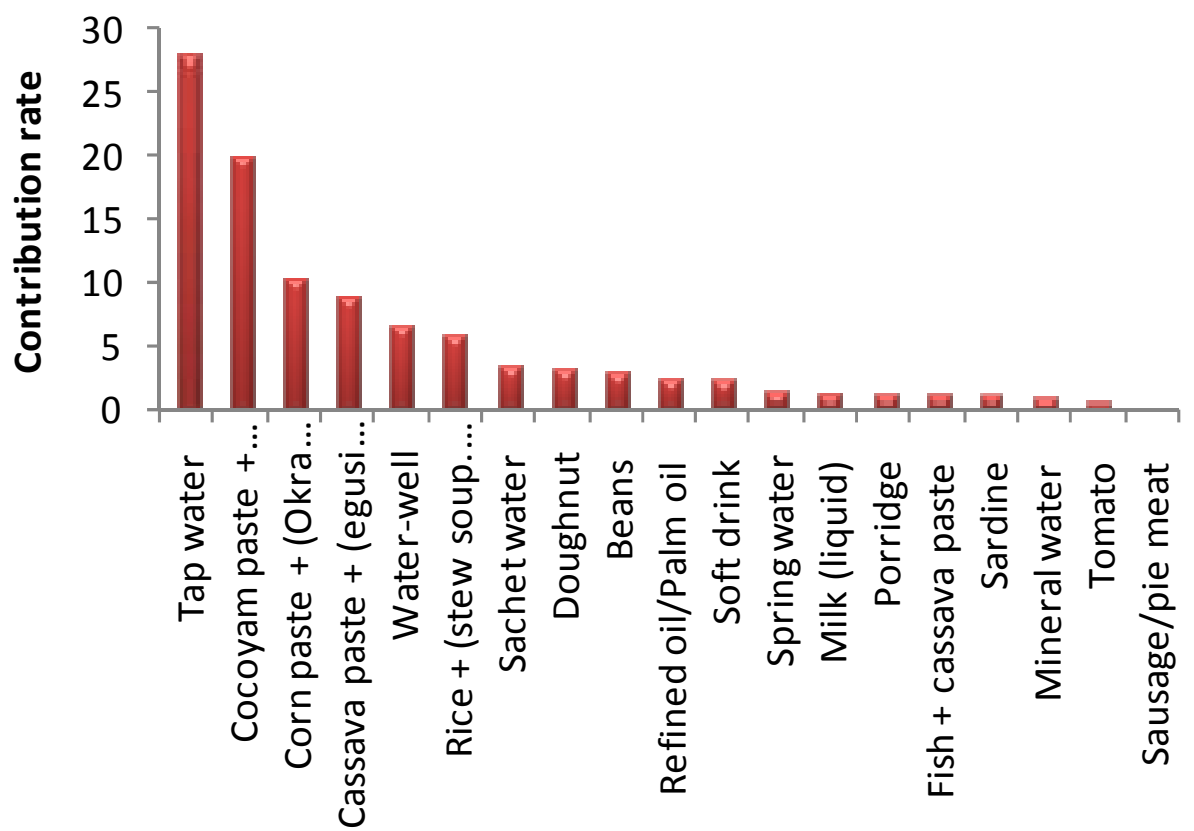

Fig. 4 Contribution of sample types to mercury exposure. 


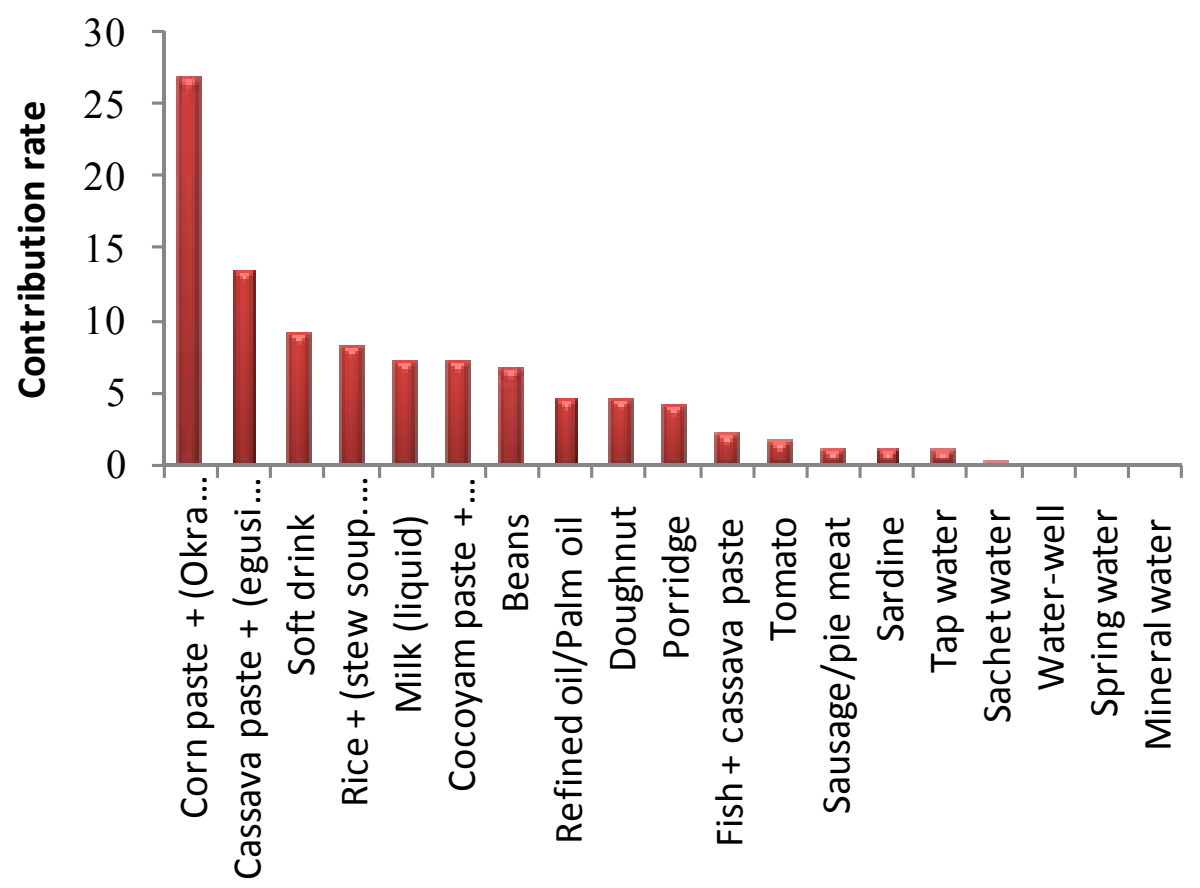

Fig. 5 Contribution of sample types to cupper exposure.

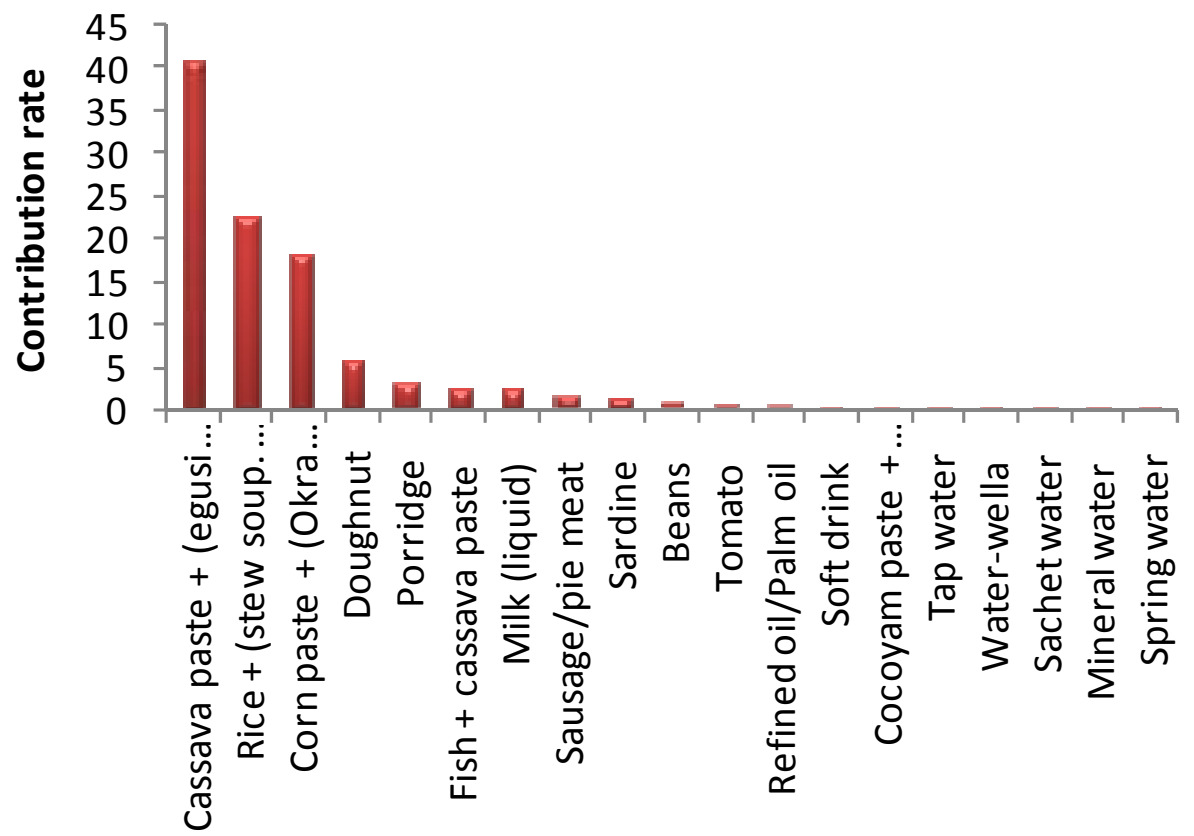

Fig. 6 Contribution of sample types to zinc exposure. 
Table 4 ADI of metals in samples group and estimated average daily intake and exposure dose to heavy metals in the study population.

\begin{tabular}{|c|c|c|c|c|c|c|c|c|c|c|c|}
\hline \multirow{3}{*}{$\begin{array}{l}\text { Heavy } \\
\text { metal }\end{array}$} & \multicolumn{6}{|c|}{ Sample groups } & \multirow{2}{*}{\multicolumn{5}{|c|}{ Estimated daily exposure dose in the study population $(n=251)$}} \\
\hline & \multicolumn{2}{|c|}{ Water (1) } & \multicolumn{2}{|c|}{ Soft drink (2) } & \multicolumn{2}{|c|}{ Food (3) } & & & & & \\
\hline & $\begin{array}{l}\text { ADI (mg/d) } \\
\text { (range) }\end{array}$ & $\begin{array}{l}\text { Contribution } \\
\text { rate }(\%)\end{array}$ & $\begin{array}{l}\text { ADI (mg/d) } \\
\text { (Range) }\end{array}$ & $\begin{array}{l}\text { Contribution } \\
\text { rate }(\%)\end{array}$ & $\begin{array}{l}\text { ADI (mg/d) } \\
\text { (Range) }\end{array}$ & $\begin{array}{l}\text { Contribution } \\
\text { rate }(\%)\end{array}$ & $\mathrm{ADI}(\mathrm{mg} / \mathrm{d})$ & $\begin{array}{l}\text { ADED } \\
(\mu \mathrm{g} / \mathrm{kg} \cdot \mathrm{bw} / \mathrm{d}) \\
(\text { range) }\end{array}$ & $p$-Value ${ }^{*}$ & $\begin{array}{l}\text { PTDI } \\
(\mu \mathrm{g} / \mathrm{kg} \cdot \mathrm{bw} / \mathrm{d})\end{array}$ & HRI \\
\hline $\mathrm{Pb}$ & $\begin{array}{l}0.09 \pm 0.18 \\
(0.003-0.96)\end{array}$ & 40.91 & $\begin{array}{l}0.07 \pm 0.37 \\
(0.01-0.12)\end{array}$ & 31.82 & $\begin{array}{l}0.06 \pm 0.77 \\
(0.001-0.38)\end{array}$ & 27.27 & $\begin{array}{l}1.1 \pm 0.49 \\
(0.22-4.23)\end{array}$ & $\begin{array}{l}18.37 \pm 8.30 \\
(3.75-70.57)\end{array}$ & 0.001 & $3.6^{*}$ & 0.0051 \\
\hline $\mathrm{Cd}$ & $\begin{array}{l}0.07^{\mathrm{d}} \pm 0.12 \\
(0.002-0.58)\end{array}$ & 1.58 & $\begin{array}{l}0.14^{\mathrm{b}} \pm 0.14 \\
(0.032-0.44)\end{array}$ & 45.16 & $\begin{array}{l}0.1^{\mathrm{c}} \pm 0.19 \\
(0.005-1.15)\end{array}$ & 32.26 & $\begin{array}{l}1.4 \pm 0.81 \\
(0.31-8.09)\end{array}$ & $\begin{array}{l}23.10 \pm 13.62 \\
(5.2-133.33)\end{array}$ & 0.001 & $1^{*}$ & 0.0231 \\
\hline $\mathrm{Hg}$ & $\begin{array}{l}0.19^{\mathrm{ad}} \pm 0.34 \\
(0.005-1.84)\end{array}$ & 65.52 & $\begin{array}{l}0.03 \pm 0.23 \\
(0.002-0.08)\end{array}$ & 10.34 & $\begin{array}{l}0.07 \pm 0.19 \\
(0.001-1.72)\end{array}$ & 24.14 & $\begin{array}{l}1.32 \pm 0.65 \\
(0.11-3.83)\end{array}$ & $\begin{array}{l}21.74 \pm 10.91 \\
(1.83-63.13)\end{array}$ & 0.001 & $0.23^{*}$ & 0.0945 \\
\hline $\mathrm{Cu}$ & $\begin{array}{l}0.07^{\mathrm{d}} \pm 0.34 \\
(0.001-0.8)\end{array}$ & 2.78 & $\begin{array}{l}1.34^{b} \pm 0.99 \\
(0.12-3.76)\end{array}$ & 53.17 & $\begin{array}{l}1.11^{\mathrm{c}} \pm 1.21 \\
(0.047-5.42)\end{array}$ & 44.05 & $\begin{array}{l}12.85 \pm 8.93 \\
(2.27-81.10)\end{array}$ & $\begin{array}{l}210 \pm 140 \\
(30-1,350)\end{array}$ & 0.001 & $160^{* *}$ & 0.0013 \\
\hline $\mathrm{Zn}$ & $\begin{array}{l}0.06^{\mathrm{d}} \pm 0.13 \\
(0.002-0.6)\end{array}$ & 0.2 & $\begin{array}{l}0.59^{\mathrm{bd}} \pm 0.58 \\
(0.017-1.56)\end{array}$ & 1.96 & $\begin{array}{l}29.45^{\mathrm{cd}} \pm \\
116.3 \\
(0.097-601.6)\end{array}$ & 97.84 & $\begin{array}{l}170.28 \pm 93.01 \\
(12.60-534.88)\end{array}$ & $\begin{array}{l}2,830 \pm 1,550 \\
(210-8,810)\end{array}$ & 0.001 & $700 * *$ & 0.004 \\
\hline
\end{tabular}

Mean \pm SD: Mean \pm standard deviation, significantly different at $p<0.05$ in samples analyzed, ${ }^{a}$ : Different when compared to values of (1); ${ }^{b}$ : Different when compared to values of (2); ${ }^{c}$ : Different when compare to values of (3); ${ }^{d}$ : Different when comparing values of (1), (2) and (3); ADI: average daily intake, ADED: average daily exposure dose, PTDI: provisional tolerable daily intake, ${ }^{*}$ PTDI established by the Joint FAO/WHO Expert Committee on Food Additives [34], ** safe upper level recommended by the Expert Group on Vitamins and Minerals (EVM) [35]; HRI: Health Risk Index. 
Table 5 Mean heavy metal daily exposure $(\mathrm{mg} / \mathrm{d})$ and relative contribution rate $(\%)$ of samples.

\begin{tabular}{|c|c|c|c|c|c|c|c|c|c|c|c|}
\hline Sample type & Food-base & $\begin{array}{l}\mathrm{Pb} \\
(\mathrm{mg} / \mathrm{d})\end{array}$ & $\begin{array}{l}\text { Contribu } \\
\text { tion rate }\end{array}$ & $\begin{array}{l}\mathrm{Cd} \\
(\mathrm{mg} / \mathrm{d})\end{array}$ & $\begin{array}{l}\text { Contribu } \\
\text { tion rate }\end{array}$ & $\begin{array}{l}\mathrm{Hg} \\
(\mathrm{mg} / \mathrm{d})\end{array}$ & $\begin{array}{l}\text { Contribu } \\
\text { tion rate }\end{array}$ & $\begin{array}{l}\mathrm{Cu} \\
(\mathrm{mg} / \mathrm{d})\end{array}$ & $\begin{array}{l}\text { Contribu } \\
\text { tion rate }\end{array}$ & $\begin{array}{l}\mathrm{Zn} \\
(\mathrm{mg} / \mathrm{d})\end{array}$ & $\begin{array}{l}\text { Contribu } \\
\text { tion rate }\end{array}$ \\
\hline $\begin{array}{l}\text { Corn paste + (Okra soup. cabbage sauce. } \\
\text { "djama-djama", "ndolè" sauce }\end{array}$ & Corn food-base & 0.47 & 13.17 & 0.361 & 14.38 & 0.24 & 10.4 & 7.671 & 26.92 & 86.913 & 17.9 \\
\hline Cassava paste + (egusi sauce ${ }^{\mathrm{a}}$. "eru" & Tuber (cassava flour) & 0.062 & 1.74 & 0.273 & 10.87 & 0.205 & 8.9 & 3.864 & 13.56 & 197.48 & 40.68 \\
\hline Cocoyam paste + peanut sauce ${ }^{\mathrm{a}}$ & Tuber (cocoyam) & 0.111 & 3.11 & 0.311 & 12.39 & 0.462 & 20 & 2.034 & 7.14 & 0.427 & 0.088 \\
\hline Rice + (stew soup. peanut sauce) & Cereals (rice) & 0.189 & 5.3 & 0.296 & 11.79 & 0.132 & 5.71 & 2.38 & 8.35 & 109.62 & 22.6 \\
\hline Doughnut & Cereals (wheat, corn) & 0.095 & 2.7 & 0.177 & 7.05 & 0.07 & 3.1 & 1.318 & 4.62 & 28.215 & 5.81 \\
\hline Porridge & $\begin{array}{l}\text { Cereals (corn, rice). } \\
\text { leguminous (peanut, beans) }\end{array}$ & 0.043 & 1.21 & 0.124 & 4.94 & 0.024 & 1.04 & 1.201 & 4.21 & 15.167 & 3.12 \\
\hline Beans & $\begin{array}{l}\text { Leguminous ( beans), tuber } \\
\text { (sweet potatoes) }\end{array}$ & 0.039 & 1.1 & 0.17 & 6.77 & 0.064 & 2.8 & 1.933 & 6.78 & 3.489 & 0.72 \\
\hline Fish + cassava paste & Fish. tuber (cassava) & 0.023 & 0.65 & 0.025 & 0.99 & 0.022 & 0.96 & 0.625 & 2.19 & 12.308 & 2.53 \\
\hline Sausage/pie meat & & 0.033 & 0.92 & 0.016 & 0.63 & 0.001 & 0.043 & 0.333 & 1.17 & 7.283 & 1.5 \\
\hline Sardine & & 0.017 & 0.48 & 0.017 & 0.67 & 0.021 & 0.91 & 0.333 & 1.17 & 6.879 & 1.41 \\
\hline Tomato & & 0.017 & 0.48 & 0.037 & 1.47 & 0.012 & 0.519 & 0.480 & 1.68 & 2.414 & 0.497 \\
\hline Milk (liquid) & & 0.075 & 2.1 & 0.036 & 1.43 & 0.025 & 1.1 & 2.042 & 7.17 & 12.247 & 2.52 \\
\hline Refined oil/Palm oil & & 0.109 & 3.1 & 0.058 & 2.31 & 0.055 & 2.4 & 1.325 & 4.65 & 1.59 & 0.33 \\
\hline Soft drink & & 0.129 & 3.61 & 0.263 & 10.47 & 0.050 & 2.19 & 2.616 & 9.18 & 1.13 & 0.233 \\
\hline Mineral water & & 0.068 & 1.9 & 0.015 & 0.59 & 0.019 & 0.83 & 0.002 & 0.007 & 0.008 & 0.0016 \\
\hline Sachet water & & 0.035 & 0.98 & 0.032 & 1.27 & 0.077 & 3.34 & 0.035 & 0.13 & 0.025 & 0.005 \\
\hline Water-well $^{\mathrm{a}}$ & & 0.026 & 0.73 & 0.04 & 1.59 & 0.151 & 6.54 & 0.010 & 0.035 & 0.042 & 0.008 \\
\hline Spring water & & 0.025 & 0.7 & 0.010 & 0.39 & 0.028 & 1.22 & 0.003 & 0.01 & 0.005 & 0.001 \\
\hline Tap water ${ }^{\mathrm{a}}$ & & 2 & 56.02 & 0.251 & 10 & 0.646 & 28 & 0.293 & 1.03 & 0.226 & 0.047 \\
\hline \multirow[t]{2}{*}{ Dietary exposure } & & 3.57 & & 2.51 & & 2.31 & & 28.5 & & 485.5 & \\
\hline & & & 100 & & 100 & & 100 & & 100 & & 100 \\
\hline
\end{tabular}

a: Sample type from households. 
Table 6 Estimated average daily exposure dose of heavy metals in the studied population.

\begin{tabular}{llllll}
\hline \multirow{2}{*}{ Professional status } & \multicolumn{5}{c}{ ADED in the study population $(\mu \mathrm{g} / \mathrm{kg}$ bw/d) (range) } \\
\cline { 2 - 6 } & $\mathrm{Pb}$ & $\mathrm{Cd}$ & $\mathrm{Hg}$ & $\mathrm{Cu}$ & $\mathrm{Zn}$ \\
\hline \multirow{2}{*}{ Employees } & $16.83 \pm 15.32$ & $20.94 \pm 21.02$ & $18.51 \pm 18.02$ & $0.2 \pm 0.1$ & $2.46 \pm 2.55$ \\
& $(7.63-33.32)$ & $(5.1-70.75)$ & $(4.55-57.03)$ & $(0.05-1.35)$ & $(0.21-6.83)$ \\
Students & $14.79 \pm 15.55$ & $19.84 \pm 20.45$ & $14.94 \pm 14.24$ & $0.2 \pm 0.5$ & $2.37 \pm 2.15$ \\
& $(3.75-70.57)$ & $(5.2-133.33)$ & $(1.83-43.64)$ & $(0.04-0.74)$ & $(0.7-8.81)$ \\
Informal Sector Workers & $19.31 \pm 16.69$ & $23.97 \pm 19.58$ & $23.82 \pm 24$ & $0.22 \pm 0.2$ & $2.97 \pm 3.25$ \\
& $(5.04-51.91)$ & $(5.38-69.05)$ & $(4.9-63.13)$ & $(0.04-1.08)$ & $(0.33-7.41)$ \\
Others & $20.85 \pm 19.52$ & $27.52 \pm 26.23)$ & $23.6 \pm 23.10$ & $0.25 \pm 0.28$ & $3.76 \pm 3.3$ \\
p-Value & $(9.69-24.75)$ & $(10.12-36.23)$ & $(11.67-28.68)$ & $(0.08-0.33)$ & $(1.77-4.24)$ \\
PTDI & 0.044 & 0.378 & 0.001 & 0.776 & 0.153 \\
\hline
\end{tabular}

Values are presented as mean \pm standard deviation, significantly different at $p<0.05$; ADED: average daily exposure dose; PTDI: provisional tolerable daily intake; *: PTDI established by the Joint FAO/WHO Expert Committee on Food Additives [34]; ** safe upper level recommended by the Expert Group on Vitamins and Minerals (EVM) [35].

\section{Discussion}

The present study investigated the exposure of the population $(n=251)$ from all 23 districts in the capital city of Cameroon, Yaoundé, to heavy metals originating from foods/snacks, water and/or soft drinks. Hazardous naturally occurring heavy metals $(\mathrm{Cd}, \mathrm{Pb}$ and $\mathrm{Hg})$ which are toxic at low concentrations, as well as trace elements or essential metals $(\mathrm{Cu}$ and $\mathrm{Zn}$ ) which are useful to the body at low concentrations, were concerned. The procedure was used for exposure/health risk assessment, included food survey, chemicals determination in popularly table-ready foodstuffs and estimation of dietary exposure dose of the population.

From the food survey, $33 \%$ of students, $20 \%$ of employees and $5 \%$ of others fed mainly in households probably due to their request programme. The observation that covers $70 \%$ of studied participants (Fig. 1) either get their foods, water and/or soft drinks from small-road-side restaurants $(70 \%)$ or from both household and small-road side restaurants (76\%) may be partly explained by the proximity to, the affordability and flexibility of the small road-side restaurants-foods, water and/or soft drinks in addition to the nature of their activities and location of these restaurants which are generally around their workplaces. Similarly, considering the busy nature of city life (each person working hard to meet up with city demands - bills, rents, family), it is obvious that many people will go in for fast foods and/or lunch bowls. This may be part of the influential factors towards the continuous expose of studied participants to heavy metals in their diets, water and/or soft drinks. Additionally, the observed high levels of contamination by heavy metals may partly be due to the generally inadequate knowledge on basic food safety and foods hygiene by the small road-side-food sellers especially as their restaurants are exposed along the major runways. This can be supported by the findings from the study conducted in Spain [36], that revealed an increased content of lead (from 0.5400 to $2.1000 \mu \mathrm{g} / \mathrm{g}$ ) and cadmium (from 0.1431 to $0.2398 \mu \mathrm{g} / \mathrm{g}$ ) in small road-side vended foods after 2 hours exposure to environment. Furthermore, exposure to the metals could be accentuated by the poor quality of the final-consumed foods considering local restaurant sellers generally wrap the foods, even while still hot, with wrapping papers, which are plastic in nature and may further contaminate the foods.

The average contents of $\mathrm{Pb}, \mathrm{Cd}$ and $\mathrm{Hg}$ in $100 \%$ contaminated water samples (sachet water, tap water, water from wells, spring water and mineral water) were 19-380 times higher than the permissible limits $[32,33]$ (Table 2), with the exception of $\mathrm{Zn}$ and $\mathrm{Cu}$ 
contents. Maximum levels of $\mathrm{Cu}, \mathrm{Zn}, \mathrm{Hg}$ and $\mathrm{Cd}$ in water were provided by sachet water and $\mathrm{Pb}$ by mineral water. Metals levels in this study were higher than reported in Nigeria [37] and Uganda [24]. Sachets water currently sold and consumed by the majority of small road-side business people or sachet water vendors in the streets of Yaoundé is from doubtful origins. This sachet water speculatively may likely be produced in households from tap water and/or groundwater. As such, contamination of the sachet water could originate from multiple sources, including contaminated soil, the use of heavy metals in the domestic drinking water supply systems [38], the manufacturing process of plastic material into which some analyzed samples were packaged [1, 39]. Runoff from urban storms and leaching of metals from household waste and soluble metal residues could also bring in heavy metals into the ground waters (spring and well water) [40].

The average contents of heavy metals in bottle soft drink samples and sachet soft drink were 1.4 to 350 times higher than the standards of $0.05 \mathrm{mg} / \mathrm{kg}$ for $\mathrm{Pb}$, 0.4- $0.5 \mathrm{mg} / \mathrm{kg}$ for $\mathrm{Cd}, 0.001 \mathrm{mg} / \mathrm{kg}$ for $\mathrm{Hg}, 5 \mathrm{mg} / \mathrm{kg}$ for $\mathrm{Cu}$ and $\mathrm{Zn}$ recommended [32, 33]. With the exception of lead, the significantly $(p>0.05)$ high levels of heavy metals revealed in bottled soft drink samples could be due to their uptake and accumulation at any point of the production chain: soil contamination, handling of raw materials and state of water utilized, storage conditions, processing and/or packaging [39, 41]. A similar observation was reported in Nigeria [42] where $\mathrm{Pb}(0.17$ to $3.39 \mathrm{mg} / \mathrm{L})$, $\mathrm{Hg}(0.29$ to $11.32 \mathrm{mg} / \mathrm{L})$ and $\mathrm{Cd}(0.149 \mathrm{mg} / \mathrm{L})$ were detected in soft drink with highest levels found in bottled samples.

When considering food samples, the average heavy metal contents of $100 \%$ contaminated samples with $\mathrm{Pb}$ and $\mathrm{Cd}, 72.54 \%$ with $\mathrm{Hg}$ and $16.66 \%$ with $\mathrm{Zn}$ exceeded from 0.6 to 15.2 folds the standards [33] excepted $\mathrm{Cu}$ (Table 2). The wide handling of foods and applications of heavy metals, incineration and/or the presence of garbage dumps, one may speculate high accumulations of heavy metals in food chains, in other food commodities, in water utilized during cooking process or production, and likelihood that, atmospheric pollution, urban wastes, vehicle emissions, poor packaging of meals may have contributed to extending the level of contamination recorded in some samples [22, 36, 43]. Heavy metals including $\mathrm{Pb}, \mathrm{Cd}, \mathrm{Hg}$ and $\mathrm{Zn}$ are reported to be used in the manufacturing process of plastics, kitchen utensils, preserved and cans coating $[1,44]$. It resulted from the survey sheets that artisanal aluminum cookware and ladles, tap water and water from wells were commonly used in cooking process and plastic materials for storage. Findings from this present study indicate a significant variation $(p<0.05)$ between samples levels of $\mathrm{Pb}$ and $\mathrm{Cd}$ and the storage material used (Table 3). The metals may have migrated into food. In addition, investigation on these kitchen utensils in Cameroon [44] revealed that substantial amounts of $\mathrm{Pb}, \mathrm{Cd}$ and other metals can migrate from artisanal cookware during cooking and enter the food. Furthermore, the repeated re-heating of food packaging in plastics, or through or through the cookware as recorded during the survey may also increase the potential for metals build-up in the food.

Daily estimated intake of metals from analyzed samples showed that, water was the most dietary source of $\mathrm{Pb}$ and $\mathrm{Hg} \quad(40.91 \%$ and $65.52 \%$ respectively). Soft drink contributed for $45.16 \%$ and $53.17 \%$ to $\mathrm{Cd}$ and $\mathrm{Cu}$ intake respectively while food contributed for $97.84 \%$ to zinc intake (Table 4). Despite the fact that refined oil, soft drink, cocoyam paste/peanut sauce and cassava paste (water "fufu")/“eru" provided highest concentrations of $\mathrm{Pb}$, $\mathrm{Cd}$ and $\mathrm{Cu}, \mathrm{Hg}, \mathrm{Cu}$ and $\mathrm{Zn}$ respectively, the main source of dietary exposure to lead and mercury was tap water (contribution rate 56.02 and $28 \%$, respectively), followed respectively by corn-rice-food-bases and cocoyam-corn food-bases. The main source of dietary cadmium exposure was 
corn food-base followed by cocoyam-rice food-bases; corn food-base for cupper followed by cassava food-base and soft drink; cassava food-base for zinc followed by rice-corn food-bases (Table 5, Figs. 2-6). Taken all together, tap water was likely to have provided highest daily intake of $\mathrm{Pb}, \mathrm{Cd}, \mathrm{Hg}, \mathrm{Cu}$ and $\mathrm{Zn}$ due to its most frequent usages such as intake as drinking water, use in preparation/processing and cooking and the high content of metals recorded in the analyzed samples.

The daily exposure dose of the study population was derived from ADI, and showed significant $(p<$ 0.05 ) variations between different heavy metals (Table 4) and some participants (informal sector workers and others) (Table 6). The daily exposure values of $\mathrm{Pb}, \mathrm{Cd}$ and $\mathrm{Hg}$ were up to 5.1; 23.1 and 94.5 times respectively higher than the regulated provisional tolerable daily intake (PTDI) [34] (Table 4). The daily exposure doses of $\mathrm{Cu}$ and $\mathrm{Zn}$ were 1.3 and 4 times respectively than the safe upper levels recommended [35]. Despite these observations, the health risk index indicated no level of concern for $\mathrm{Pb}, \mathrm{Cd}, \mathrm{Hg}, \mathrm{Cu}$ and Zn $($ HRI $<1)$. However, regular consumption of such contaminated food may lead to bioaccumulation of the heavy metals in the body at levels exceeding the PTDI, which may have negative health implications. The adverse effects of heavy metals as endocrine disruptors and/or inducers of serious long-term illnesses such as cancer, metabolic diseases, neurodegenerative diseases, infertility, etc., is well documented $[4,15,16]$.

\section{Conclusions}

This investigation showed high occurrence frequencies of heavy metals in foods (food items, ready-to-eat foods), water from different sources (tap, mineral, spring, wells) and soft drinks commonly consumed by individuals in Yaoundé-Cameroon. Those from street restaurants infatuated by workers from informal sector were the most contaminated. They are sufficient evidence to suggest through this pilot study that, Cameroonians are exposed to heavy metals at levels above the acceptable PTDI thresholds. The main source of exposure to $\mathrm{Pb}$ and $\mathrm{Hg}$ was tap water, and the staple cereals and tubers food-base for $\mathrm{Cd}, \mathrm{Cu}$ and $\mathrm{Zn}$. The health risks levels of the population towards these metals were found to be safe $(<1)$, However, further or continuous exposure may lead to health implication. A correlation study of heavy metals and other environmental toxicants in food to levels of suitable biomarkers to accurately estimate the degree of human exposure via urine, educational intervention to control foods contamination in order to reduce human exposure including susceptible populations, such as children to these toxic substances is necessary.

\section{Acknowledgements}

The authors are grateful to the participants for their cooperation, to Dr. Akindeh for the assistance during data analysis and the Institute of Research for Agriculture and Development (IRAD), Yaoundé for atomic absorption analysis.

\section{References}

[1] Biney, C., Amuzu, A. T., Calamari, D., Kaba, N., Mbome, I. L., Naeve, H., et al. 1995. "Revue de la pollution dans l'environnement aquatique africain: Etude des métaux lourds." In Archives de documents de la FAO, Département de pêches. Rome, pp. 25-9.

[2] Bortey-Sam, N., Nakayama, S.M., Ikenaka, Y., Akoto, O., Baidoo, E., Yohannes, Y. B., et al. 2015. "Human Health Risks from Metals and Metalloid via Consumption of Food Animals near Gold Mines in Tarkwa, Ghana: Estimation of Daily Intakes and Target Hazard Quotients (THQs)." Ecotoxyco. Environ. Saf. 111: 160-7.

[3] Wong, J. W. 1996. "Heavy Metal Contents in Vegetables and Market Garden Soils in Hong Kong." Environmental Technology 17: 407-14.

[4] Manfo, F. P. T., Nantia, E. A., Wang, K. L., Moundipa, P. F., and Mathur, P. P. 2014. "Heavy Metal-Induced Toxicity on Male Reproductive Function." In Contemporary Topics in Life Sciences, edited by Mathur, P. P., Narendra Publishing House, pp. 1-26.

[5] Okereke Chioma, J., Essien, E. B., and Wegwu, M. O. 2016. "Human Health Risk Assessment of Heavy Metal Contamination for Population via Consumption of 
Selected Vegetables and Tubers Grown in Farmlands in Rivers State, South-South Nigeria.” J. Anal. Pharm. Res. 3 (6): 1-10.

[6] Adei, E., and Forson-Adaboh, K. 2008. "Toxic (Pb, Cd, $\mathrm{Hg}$ ) and Essential ( $\mathrm{Fe}, \mathrm{Cu}, \mathrm{Zn}, \mathrm{Mn})$ Metal Content of Liver Tissue of Some Domestic and Bush Animals in Ghana." Food Addit Contam Part B Surveill. 1 (2):100-5.

[7] Hosseini, M., Nabavim S. M., Nabavim S. N., and Pour, N. A. 2015. "Heavy Metals (Cd, Co, Cu, Ni, Pb, Fe, and $\mathrm{Hg}$ ) Content in Four Fish Commonly Consumed in Iran: Risk Assessment for the Consumers." Environ Monit Assess. 187 (5): 237.

[8] DEFRA (Department of Environment, Food and Rural Affairs). 1999. Total Diet Study-Aluminium, Arsenic, Cadmium, Chromium, Copper, Lead, Mercury, Nickel, Selenium, Tin and Zinc. London: The Stationery Office.

[9] Cambra, K., Martinez, T., Urzelai, A., and Alonso, E. 1999. "Risk Analysis of a Farm Area near a Lead- and Cadmium-Contaminated Industrial Site." Journal of Soil Contain 8: 527-40.

[10] Hammi, H. 2010. La pollution des eaux par les métaux lourds. Les IIIème Olympiades Tunisiennes de Chimie.

[11] Ye, B., Kim, B., Jeon, M., Kim, S., Kim, H., Jang, T., et al. 2016. "Evaluation of Mercury Exposure Level, Clinical Diagnosis and Treatment for Mercury Intoxication." Annals of Occupational and Environmental Medicine 28: 5 .

[12] Melila, M., Poutouli, W., Amouzou, K., Tchangbedji, G., Tchaou, M., Doh, A., et al. 2012. "Induction du stress oxydatif chez l'homme suite à la bioconcentration des éléments traces métalliques (cadmium et plomb) par voie trophique à Kpémé (Sud du Togo).” Int. J. Biol. Chem. Sci. 6 (3): 1263-70.

[13] Jaishankar, M., Tseten, T., Anbalagan, N., Mathew Blessy, B., and Beeregowda, K. N. 2014. "Toxicity, Mechanism and Health Effects of Some Heavy Metals." Interdiscip Toxicol. 7 (2): 60-72.

[14] Curtin, J. F., Donovan, M., and Cotter, T. G. 2002. "Regulation and Measurement of Oxidative Stress in Apoptosis." Journal of Immunological Methods 265: 49-72.

[15] Jomova, K., and Valko, M. 2011. "Advances in Metal-Induced Oxidative Stress and Human Disease." Toxicology 283 (2-3): 65-87.

[16] Maherou, J., Norest, S., and Ferrier, L. 2013. Les métaux lourds, quels risques pour la santé? ASEF, p. 7.

[17] Long, X. X., Yang, X. E., Ni, W. Z., Ye, Z. Q., He, Z. L., Calvert, and Stoffella, J. P. 2003. "Assessing Zinc Thresholds for Phytotoxicity and Potential Dietary Toxicity in Selected Vegetables Crops." Commn. Soil Science of Plant Analogy 34 (9-10): 1421-34.

[18] Bwa, J., Bergkvist, L., Bottai, M., and Akesson, A. 2012.
"Dietary Cadmium Exposure and Risk of Postmenopausal Breast Cancer: A Population-Based Prospective Cohort Study." Cancer Research 72 (6): 145.

[19] Chen, P., Miah, M. R., and Aschner, M. 2016. "Metals and Neurodegeneration." F1000Research 5 (366): 1-12.

[20] Saha, N., and Zaman, M. R. 2012. "Evaluation of Possible Health Risks of Heavy Metals by Consumption of Foodstuffs Available in the Central Market of Rajshahi City, Bangladesh.” Environ. Monit. Assess. 185: 3867-78.

[21] Islam, M. S., Ahmed, M. K., Habibullah-Al-Mamun, M., Islam, K. N., Ibrahim, M., and Masunaga, S. 2014. "Arsenic and Lead in Foods: A Potential Threat to Human Health in Bangladesh." Food Additives \& Contaminants: Part A 31: 1982-92.

[22] Bortey-Sam, N., Nakayama, S. M., Akoto, O., Ikenaka, Y., Fobil, N. J., Baidoo, E., et al. 2015. “Accumulation of Heavy Metals and Metalloid in Foodstuffs from Agricultural Soils around Tarkwa Area in Ghana, and Associated Human Health Risks." Int. J. Environ. Res. Public Health 12: 8811-27.

[23] Iwegbue, C. M. A., Nwozo, S. O., Overah, C. L., Bassey, F. I., and Nwajei, G. E. 2013. "Concentrations of Selected Metals in Some Ready-to-Eat-Foods Consumed in Southern Nigeria: Estimation of Dietary Intakes and Target Hazard Quotients." Food Science and Technology 1 (1): 1-7.

[24] Bamuwamye, M., Ogwok, P., Tumuhairwe, V., Eragu, R., Nakisozi, H., and Ogwang, P. E. 2017. "Human Health Risk Assessment of Heavy Metalsin Kampala (Uganda) Drinking Water." Journal of Food Research 6 (4): 6-16.

[25] Fonge, B. A., Tening, A. S., Egbe, A. E., Awo, E. M., Focho, D. A., Oben, P. M., et al. 2011. "Fish (Arius heudelotii Valenciennes, 1840) as Bioindicator of Heavy Metals in Douala Estuary of Cameroon." African Journal of Biotechnology 10 (73): 16581-8.

[26] Bonglaisin, J. N., Mbofung, C. M. F., and Lantum, D. N. 2011. "Intake of Lead, Cadmium and Mercury in Kaolin-Eating: A Quality Assessment.” J. Med. Sci. 11: 267-73.

[27] Afri-Mehennaoui, F-Z., and Mehennaoui, S. 2004. "Comparaison de trois techniques d'extractions pour la détermination des éléments traces métalliques dans les sédiments de l'Oued Rhumel et son affuent l'oued Boumerzoug en zone urbaine (Constantine)." Sciences \& Technologie 12: 20-38.

[28] A.O.A.C. 1997. "Official Methods of Analysis of the Association of Official Chemist." AOAC Inc, Arlington 16 ed, 11 (37): 3-4.

[29] FAO/WHO (Food and Agriculture Organization/World Health Organization). 2005. Dietary Exposure Assessment of Chemicals in Food. report of a joint FAO/WHO consultation, Annapolis, Maryland, USA. 

Metals amongst Some Workers in Yaoundé, Cameroon

[30] WHO (World Health Organization). 2005. "Surveillance of Chronic Disease Risk Factors: Country Level Data and Comparable Estimates." Global Infobase Team: SuR Freport 2 (WHO, Geneva), p. 14.

[31] EPA (Environmental Protection Agency). 1989. Guidance Manual for Assessing Human Health Risks from Chemically Contaminated, Fish and Shellfish, US Environmental Protection Agency, Washington DC EPA-503/8-89-002.

[32] WHO (OMS: Organisation Mondiale de la Santé). 2006. Norme de l'OMS sur l'eau potable. Lenntech.

[33] European Commission (EC). 2006. "Setting Maximum Levels for Certain Contaminants in Foodstuffs." Official Journal of the European Union L364/5 Commission Regulation (EC) No. 1881/2006.

[34] JECFA (Joint FAO/WHO Expert Committee on Food Additives). 2000. "Safety Evaluation of Certain Food Additives and Contaminants." WHO Food Additives Series 44: 273-312.

[35] EVM. 2003. "Safe Upper Levels for Vitamins and Minerals of the Export Group on Vitamins and Minerals." Food Standard Agency. http://www.food.gov.uk/multimedia/pdfs /vitmin.

[36] Abdulmajid, N., Baustista, S., Chavez, E., Dimaano, W., and Barcelon, E. 2014. "Heavy Metal Assessment and Sensory Evaluation of Street Vended Foods." International Food Research Journal 21 (6): 2127-31.

[37] Abdullahi, S., Ndikilar, C. E., Suleiman, A. B., and Hafeez, H. Y. 2016. “Assessment of Heavy Metals and Radioactivity Concentration in Drinking Water Collected From Local Wells and Boreholes of Dutse Town, North
West, Nigeria." Journal of Environment Pollution and Human Health 4 (1): 1-8.

[38] EPA (Environmental Protection Agency). 2008. "Public Health Goal for Copper in Drinking Water." Office of Environmental Health Hazard Assessment; Pesticide and Environmental Toxicology branch, Oakland, California, 1: 70.

[39] Buldini, P. L., Ricci, L., and Sharma, J. L. 2002. "Recent Applications of Sample Preparations Techniques in Food Analysis." Journal of Chromatography A 975 (1): 47-70.

[40] Ahoussi, E. K., Soro, N., Kouassi, A. M., Soro, G., Koffi, Y. B., and Zade, S. P. 2010. "Application des méthodes d'analyses statistiques multivariées à l'étude de l'origine des métaux lourds $\left(\mathrm{Cu}^{2+}, \mathrm{Mn}^{2+}, \mathrm{Zn}^{2+}\right.$ et $\left.\mathrm{Pb}^{2+}\right)$ dans les eaux des nappes phréatiques de la ville d'Abidjan." International Journal of Biological and Chemical Science 4 (5): 1753-65.

[41] Galadima, A., And Garba, Z. N. 2012. "Heavy Metal Pollution in Nigeria: Causes and Consequences." Elixir Pollut. 45: 7917-22.

[42] Engwa, A. G., and Osuji, A. G. 2015. "Determination of Some Soft Drink Constituents and Contamination by Some Heavy Metal in Nigeria." Toxicology Reports 2: 384-90.

[43] Cossa, D., and Ficht, A. 1999. La dynamique du mercure, Programme scientifique Seine Aval. Editions Ifremer, Plouzané, France, p. 26.

[44] Weidenhamer, J. D., Kobunski, P. A., Kuepouo, G., Corbin, R. W., and Gottesfeld, P. 2014. "Lead Exposure from Aluminum Cookware in Cameroon." Science of the Total Environment 496: 339-47. 